Volume 10 Issue 2 (2021) Pages 285-296

Ta'dib : Jurnal Pendidikan Islam

ISSN: 2528-5092 (Online) 1411-8173 (Print)

https://ejournal.unisba.ac.id/index.php/tadib/article/view/8580

\title{
IMPLEMENTATION OF PAI LEARNING IN SCHOOL DURING THE COVID-19 PANDEMIC
}

\author{
Rachmadilla Indah Maulidina ${ }^{1}$, Udin Supriadi ${ }^{2}$ dan Agus Fakhruddin ${ }^{3}$ \\ Pendidikan Agama Islam, Pascasarjana Universitas Pendidikan Indonesia ${ }^{(1)}$ \\ Pendidikan Agama Islam, Pascasarjana Universitas Pendidikan Indonesia ${ }^{(2)}$ \\ Pendidikan Agama Islam, Pascasarjana Universitas Pendidikan Indonesia ${ }^{(3)}$ \\ DOI: $10.29313 /$ tjpi.v10i2.8580
}

\begin{abstract}
Abstrak
Praktikum merupakan salah satu bagian penting dari kegiatan pembelajaran PAI. Beberapa hasil riset menunjukkan bahwa praktikum pembelajaran PAI terlalu banyak berorientasi pada aspek kognitif. Penelitian ini bertujuan untuk mendeskripsikan pelaksanaan pembelajaran praktikum PAI di SD Negeri Cibabat Mandiri 5 dengan menggunakan pendekatan kualitatif dan metode deskriptif. Hasil penelitian menunjukkan bahwa praktikum pembelajaran PAI dalam RPP semester ganjil pada kelas genap sebanyak 13 praktikum yang meliputi aqidah, syariah dan akhlak. Perencanaan dimulai dari tujuan, materi, metode, dan evaluasi. Fasilitas yang digunakanpun terbatas. Adapun proses praktikum dilakukan secara online yang meliputi perencanaan, pelaksanaan, dan tindak lanjut yang melibatkan guru, siswa serta orangtua. Penilaian terdiri dari tes praktik, observasi dan penugasan dengan menggunakan beberapa alat penilaian seperti Al-Qur'an, buku Asmaul Husna, buku paket PAI, buku panduan shalat, video tentang kisah keteladanan Nabi, dan buku sejarah kebudayaan islam. Hasil dari praktikum diketahui semua siswa mencapai nilai diatas KKM.
\end{abstract}

Kata Kunci: Practicum, PAI Learning, Teacher Competence.

Copyright (c) 2021 Rachmadilla Indah Maulidina ${ }^{1}$, Udin Supriadi ${ }^{2}$ dan Agus Fakhruddin ${ }^{3}$.

$\triangle$ Corresponding author :

Email Address : rachmadilla.indah@upi.edu¹, udinsupriadi@upi.edu'2, agusfakhruddin@upi.edu ${ }^{3}$ Received 28/11/2021, Accepted 27/01/2022, Published 28/01/2022 


\section{PENDAHULUAN}

Aspek-aspek Pendidikan Agama Islam (PAI) meliputi usaha untuk mencapai terjadinya pengaruh terhadap kualitas luaran peserta didik. Pembelajaran dengan adanya praktikum salah satu yang paling mudah untuk membentuk pemahaman. Kurikulum yang dinamis membuat teknik pembelajaran mata pelajaran selalu berkembang dan adanya praktikum selalu menjadi aspek penting di dalamnya. Secara definisi dari Kamus Umum Bahasa Indonesia (KBBI), praktikum merupakan salah satu cara pengujian dan pelaksanaan kondisi riil dalam memahami materi yang diajarkan dengan melakukan sebuah praktik dari materi tersebut (Departemen Pendidikan Nasional, 2002).

Pendidikan Agama Islam (PAI) yang merupakan bagian dari rumpun ilmu pengajaran Islam (tarbiyah) memiliki dua aspek utama dalam pengajaran, yaitu teori dan praktik. Kedua aspek penting untuk melengkapi pemahaman teori diimbangi dengan praktiknya. Misalnya dalam pemahaman tentang ibadah dipahami teori tetapi juga dikuasai praktiknya (Kisbiyanto, 2013). Keberhasilan pembelajaran PAI salah satunya ditunjang dengan adanya praktikum.

Psikomotorik (nahiyah al-harakah) merupakan domain dasar yang membangun keterampilan (skill) atau kemampuan bertindak setelah peserta didik melalui pengalaman belajar tertentu. Domain psikomotorik tersebut menjadi dasar dalam pembuatan metode praktikum dalam pembelajaran mata pelajaran PAI. Domain psikomotorik tersebut salah satunya dikemukakan oleh Simpson (1956) dengan hasil, adanya kemampuan psikomotor yang tampak membentuk keterampilan (skill) dan kemampuan bertindak seorang individu. Dalam konteks PAI, Sudjono (2016) mencontohkan dengan peserta didik yang menjalankan praktik berupa pelaksanaan ibadah shilat, puasa, tayamum, dan lain sebagainya.

Kementerian Pendidikan dan Kebudayaan bahkan telah menetapkan legalitas praktikum sebagai bagian dari kurikulum pembelajaran PAI. Legalitas tersebut berupa landasan yuridis Peraturan Kementerian Pendidikan dan Kebudayaan Nomor 67 Tahun 2013 yang memuat Kerangka Dasar dan Struktur Kurikulum Sekolah Dasar/Madrasah Ibtidaiyah. Di dalamnya terdiri dari KI-1 (spiritual), KI-2 (sosial), KI-3 (pengetahuan), dan KI-4 (keterampilan). Selain itu, pembelajaran PAI yang disertai implementasi praktikum berlandaskan pada Al-Qur'an dan hadist. Salah satunya yang dimuat dalam QS. Al-Kahf : 7, QS. Al-Mulk : 2, dan HR. Ibnu Majah.

Pembelajaran berasal dari bahasa Inggris instruction, yang memiliki definisi berlangsungnya interaksi antara guru dan siswa secara dinamis (Asyhar, 2021). Definisi lainnya, berasal dari Huda (2014) berpendapat bahwa pembelajaran merupakan hasil dari memori, kognisi, dan metakognisi yang mempengaruhi terhadap tingkat pemahaman seseorang (siswa). Hal tersebut terjadi saat seseorang sedang belajar dan hal tersebut juga dialami sepanjang kehidupan. Berdasarkan definisi dari Asyhar (2021) dan Huda (2014) diketahui bahwa terdapat domain psikomotorik yang memiliki peran penting. Psikomotor dinilai sebagai lanjutan dari proses belajar yang memperoleh kognitif dan afektif dengan menghasilkan ekspresi berupa perilaku atau perbuatan tertentu perilaku atau perbuatan tertentu sesuai dengan makna yang terkandung dalam domain kognitif dan domain afektifnya (Sudijono, 2016). Maka dari itu, implementasi praktikum sebagai bagian dari pembelajaran PAI harus dilaksanakan sebaik dan semaksimal mungkin.

Mengacu pada beberapa penelitian terdahulu dengan mengungkap permasalahan berupa yang terjadi di sekolah. Pratiwi (2017) melakukanpenelitian di SMP Muhammadiyah 1 Surakarta pada tahun ajaran 2016/2017 total memiliki siswa kelas VIII sebanyak 228 siswa, 80 siswa diantaranya belum bisa membaca Al-Qur'an dengan lancar. Kemudian, di Madrasah Aliah Negeri I Kota Kendari terdapat sekitar 40\% dari 300 siswa kelas X yang belum fashih membaca alQuran (Ilmu Tajwid dan Tahsin) (Darwin, 2018). Selanjutnya di SD Negeri Kalimanggis Kaloran Temanggung dari 25 orang siswa di kelas IV, hanya sebanyak 56\% (14 orang) yang telah mampu melakukan praktik shalat dengan benar (Sujono, 2010). Permasalahan lainnya dalam implementasi pembelajaran PAI terjadi di SD Negeri 003 Sialang Palas Kecamatan Lubuk

286| Ta'dib : Jurnal Pendidikan Islam, 10(2), 2021 
DOI: $10.29313 /$ tjpi.v10i2.8580

Dalam Kabupaten Siak, mengungkapkan bahwa dari jumlah siswa kelas II sebanyak 29 orang, hanya 7 orang yang mampu melakukan tata cara berwudhu dengan benar (Syamsinar, 2012).

Praktikum menjadi bagian penting dalam setiap tahap pembelajaran yang tidak bisa dilewatkan. Pengaruhnya penting dalam menyempurnakan kemampuan kognitif dan afektif pserta didik. Praktikum dapat menjadi jawaban realita pasifnya peserta didik dalam keikutsertaannya dalam belajar. Hal tersebut untuk mengantisipasi hanya aspek kognitif yang tercukupi, tetapi tidak menguasai aspek psikomotorik yang mengharuskan terus-menerus melihat pedoman pembelajaran untuk praktiknya(Hadi, 2019).

Melihat realita tentang domain psikomotor dibandingkan beberapa teori pembelajaran seperti Taxonomy Bloom, Permendikbud Nomor 67 Tahun 2013, QS Al-Kahf: 7, QS. Al-Mulk : 2, dan HR. Ibnu Majah terlihat masih adanya kesenjangan berupa mayoritas guru PAI mengedepankan aspek kognitif, seringkali melewatkan aspek psikomotor. Hal tersebut tidak terjadi di semua sekolah, karena beberapa sekolah mampu menerapkan pembelajaran PAI yang seimbang antara aspek kognitif, afektif, dan psikomotorik. Salah satu di antaranya adalah SD Negeri Cibabat Mandiri 5 yang merupakan salah satu SD Negeri terbaik dalam pelaksanaan pembelajaran di Kota Cimahi, dibuktikan dengan pernah memperoleh juara perlombaan PAI, antara lain juara harapan III cabang MTQ Putra pada pentas PAI tahun 2016 tingkat Kota Cimahi, juara III cabang Kesempurnaan Gerakan dan Bacaan Shalat pada pentas PAI tahun 2017 tingkat Kota Cimahi, juara harapan II cabang MTQ Putri pada pentas PAI tahun 2018 tingkat Kota Cimahi, juara III cabang MTQ Putra pada pentas PAI tahun 2019 tingkat Kecamatan Cimahi (Susi, 2020). Selain menjuarai bidang PAI, sekolah ini pernah menjuarai beberapa perlombaan, antara lain juara I bidang Taekwondo tingkat Kota Cimahi, juara II Futsal tingkat Kota Cimahi, juara III Marching Band tingkat Kota Cimahi, juara II Karate tingkat Kota Cimahi, dan juara I Taekwondo tingkat Jawa Barat. Adapun prestasi lain yang diraih SD Negeri Cibabat Mandiri 5 yaitu sering masuk ke dalam kategori nilai UN terbesar tingkat Kota Cimahi (Ulan, 2020).

Secara umum, tujuan penelitian ini adalah untuk mendeskripsikan tentang implementasi praktikum pembelajaran PAI pada masa pandemi covid-19 di SD Negeri Cibabat Mandiri 5. Adapun secara khusus, tujuan penelitian ini adalah untuk mendeskripsikan praktikum pembelajaran PAI pada masa pandemi covid-19 di SD Negeri Cibabat Mandiri 5, mendeskripsikan perencanaan praktikum pembelajaran PAI pada masa pandemi covid-19 di SD Negeri Cibabat Mandiri 5, mendeskripsikan fasilitas yang digunakan sebagai penunjang praktikum pembelajaran PAI pada masa pandemi covid-19 di SD Negeri Cibabat Mandiri 5, mendeskripsikan proses praktikum pembelajaran PAI pada masa pandemi covid-19 di SD Negeri Cibabat Mandiri 5, dan mendeskripsikan penilaian praktikum pembelajaran PAI pada masa pandemi covid-19 di SD Negeri Cibabat Mandiri 5.

\section{METODOLOGI}

Penelitian ini menggunakan pendekatan kualitatif. Penelitian dengan pendekatan kualitatif diartikan sebagai serangkaian penelitian untuk memperoleh pemahaman yang baru dengan kompleksitas, detail, dan tingkat komprehensifitas yang lebih akan suatu topik penelitian (Anggito dan Setiawan, 2018). Penelitian kemudian mengambil metode deskriptif yang membuat penelitian mampu melakukan deskripsi dan mengurasi pertanyaan-pertanyaan penelitian seputar topik penelitian. Dalam penelitian dapat menggunakan variabel tunggal atau disertai dengan adanya korelasi atau perbandingan antar variabel (Arifin, 2014). Metode deskriptif dipilih untuk menyusun sebuah deskripsi, gambaran atau lukisan secara sistematis, faktual dan akurat mengenai faktafakta, sifat-sifat serta hubungan antar fenomena yang diselidiki (Tarjo, 2019). Adapun instrumen penelitiannya yaitu menggunakan studi observasi, studi wawancara, dan studi dokumentasi. Setelah memperolah data, kemudian peneliti akan menganalisis untuk menjawab rumusan masalah.

Data penelitian diperoleh dengan menentukan sampel penelitian sebagai sumber informasi diantaranya guru PAI, perwakilan siswa dari kelas 2, 4, dan 6. Selain itu, sampel penelitian juga 
melibatkan orangtua siswa dari kelas 2, 4, dan 6 serta beberapa karyawan bagian tata usaha di SD Negeri Cibabat Mandiri 5. Penelitian ini berlokasi di Jalan. Pesantren Nomor 86A, Cibabat, Kecamatan Cimahi Utara, Kota Cimahi, Provinsi Jawa Barat. Waktu penelitian yang digunakan yaitu dari bulan Agustus-Desember. Sebelumnya, peneliti telah melaksanakan studi pendahuluan berupa wawancara kepada guru PAI yang mana SD Negeri Cibabat Mandiri 5 merupakan salah satu sekolah yang tetap melaksanakan praktikum pembelajaran PAI walaupun secara daring.

\section{HASIL DAN PEMBAHASAN}

\section{Bentuk Praktikum}

Pembelajaran PAI pada Masa Pandemi Covid-19 di SD Negeri Cibabat Mandiri 5

Praktikum pembelajaran PAI memiliki peran bagi peserta didik untuk belajar dengan motivasi tinggi sehingga terus dapat mempelajari agama Islam. PAI tidak hanya dipelajari sebagai bagian dari kewajiban kurikulum sekolah tetapi juga sebagai cara untuk mengenal agama Islam yang melengkapi aspek kognitif, afektif, dan psikomotorik seorang siswa dalam tingkah lakunya di keseharian (Majid dan Andayani, 2006). Bentuk-bentuk praktikum ini berbeda antara satu dengan lainnya.

Berdasarkan temuan dilapangan, praktikum pembelajaran PAI terbagi ke dalam kategori aqidah, syariah, dan akhlak. Sesuai pendapat (Burhanuddin, 2014) lingkup bahan pembelajaran PAI pada dasarnya mencakup keimanan/aqidah, syariah, dan akhlak. Untuk melaksanakan praktikum, tentu ada landasannya yaitu kurikulum. Kurikulum membuat proses belajar membekas sebagai bagian dari membentuk kedewasaan. Tidak hanya sebagai mata pelajaran di sekolah, tetapi sebagai pedoman berinteraksi dengan sesama di lingkungan sekolah, dalam kelompok, maupun dengan masyarakat luas (Tafsir, 1992). Adapun jumlah praktikum dalam kurikulum Sekolah Dasar yaitu sebanyak 110 praktikum. Seperti yang telah dikatakan bahwa fungsi kurikulum dalam praktikum pembelajaran mata pelajaran Pendidikan Agama Islam memiliki fungsi preventif yang memberikan panduan bagi guru dalam melaksanakan program pembelajaran (Chamisijatin dan Permana, 2019). Kurikulum menjadi acuan dalam proses pembelajaran, sehingga kurikulum menjadi program yang dirancang untuk mencapai tujuan pendidikan yang diharapkan. Praktikum dalam lingkup aqidah sebanyak 11 praktikum, lingkup syariah sebanyak 18 praktikum, dan lingkup akhlak sebanyak 56 praktikum. Bentuk praktikum dalam kurikulum lebih banyak bagian akhlak daripada syari'ah dan aqidah.

Praktikum dalam lingkup aqidah antara lain 4.3 menunjukkan bukti-bukti adanya Allah Swt. yang Maha Pengasih dan Maha Penyayang; 4.4 menunjukkan bukti-bukti keesaan Allah Swt. berdasarkan pengamatan terhadap dirinya dan makhluk ciptaan-Nya yang dijumpai di sekitar rumah dan sekolah; 4.6 melafalkan dua kalimat syahadat dengan benar dan jelas; 4.3 melakukan pengamatan terhadap diri dan makhluk ciptaan Allah yang dijumpai di sekitar rumah dan sekolah sebagai implementasi iman terhadap keesaan Allah Yang Maha Pencipta; 4.2 melakukan pengamatan terhadap makhluk ciptaan Allah di sekitar rumah dan sekolah sebagai upaya mengenal Allah itu ada; 4.4 melakukan pengamatan diri dan alam sekitar sebagai implementasi makna iman kepada malaikat-malaikat Allah; 4.5 mencontohkan makna iman kepada Rasul Allah; 4.3 menunjukkan hafalan nama-nama Rasul Allah dan Rasul Ulul 'Azmi; 4.4 menunjukkan makna kitab-kitab suci melalui rasul-rasul-Nya sebagai implementasi rukun iman; 4.3 menunjukkan contoh hikmah beriman kepada hari akhir yang dapat membentuk perilaku akhlak mulia; 4.4 menunjukkan hikmah beriman kepada qadha dan qadar yang dapat membentuk perilaku akhlak mulia.

Kemudian, yang termasuk ke dalam syari'ah antara lain 4.7 melafalkan doa sebelum dan sesudah belajar dengan benar dan jelas; 4.11 mempraktikkan tata cara bersuci; 4.12.1 melaksanakan salat dan kegiatan agama di sekitar rumahnya melalui pengamatan; 4.12 .2 mencontohkan kegiatan agama di sekitar rumahnya; 4.3 menunjukkan perilaku rajin belajar sebagai implementasi pemahaman makna Hadis yang terkait dengan anjuran menuntut ilmu; 4.4 
DOI: $10.29313 /$ tjpi.v10i2.8580

menunjukkan perilaku hidup bersih dan sehat sebagai implementasi pemahaman makna Hadis tentang kebersihan dan kesehatan; 4.6 melafalkan doa sebelum dan sesudah makan; 4.9 mempraktikkan wudu dan doanya dengan tertib dan benar; 4.10 mempraktikkan salat dengan tata cara dan bacaan yang benar; 4.8 menunjukkan contoh makna salat sebagai wujud dari pemahaman QS. Al-Kausar; 4.9 mempraktikkan tata cara zikir dan doa setelah salat secara benar; 4.10 menceritakan pengalaman hikmah pelaksanaan ibadah salat di rumah dan sekolah; 4.14 mempraktikkan tata cara bersuci dari hadas kecil sesuai ketentuan syari'at Islam; 4.15.1 menunjukkan contoh makna ibadah salat; 4.15.2 menceritakan pengalaman melaksanak-an salat di rumah dan masjid lingkungan sekitar rumah; 4.10 menunjukkan hikmah puasa Ramadan yang dapat membentuk akhlak mulia; 4.11 mempraktikkan tatacara salat tarawih dan tadarus AlQur'an; 4.7 menunjukkan hikmah zakat, infaq, dan sedekah sebagai implementasi rukun Islam.

Yang termasuk ke dalam akhlak antara lain 4.8 mencontohkan perilaku hormat dan patuh kepada orangtua dan guru; 4.9 mencontohkan cara berkata yang baik, sopan, dan santun; 4.10 mencontohkan perilaku bersyukur, pemaaf, jujur, dan percaya diri; 4.13 menceritakan kisah keteladanan Nabi Adam a.s; 4.14 menceritakan kisah keteladanan Nabi Idris a.s; 4.15 menceritakan kisah keteladanan Nabi Nuh a.s; 4.16 menceritakan kisah keteladanan Nabi Hud a.s; dan 4.17 menceritakan kisah keteladanan Nabi Muhammad saw; 4.7 mencontohkan perilaku kasih sayang kepada sesama; 4.8 mencontohkan sikap kerja sama dan saling tolong menolong; 4.11 menceritakan kisah keteladanan Nabi Saleh a.s; 4.12 menceritakan kisah keteladanan Nabi Lut a.s; 4.13 menceritakan kisah keteladanan Nabi Ishaq a.s; 4.14 menceritakan kisah keteladanan Nabi Ya'qub a.s; dan 4.15 menceritakan kisah keteladanan Nabi Muhammad SAW; 4.2 mencontohkan perilaku mandiri, percaya diri, dan bertanggung jawab sebagai implementasi makna Hadis yang terkandung; 4.5 mencontohkan perilaku tawaduk, ikhlas, dan mohon pertolongan; 4.6 mencontohkan perilaku peduli terhadap sesama sebagai implementasi pemahaman QS. Al-Kausar; 4.7 mencontohkan sikap bersyukur; 4.11 menceritakan kisah keteladanan Nabi Yusuf a.s; 4.12 menceritakan kisah keteladanan Nabi Syu'aib a.s; 4.13 menceritakan kisah keteladanan Nabi Ibrahim a.s. dan Nabi Ismail a.s; dan 4. 14 menceritakan kisah keteladanan Nabi Muhammad saw; 4.6 mencontohkan sikap santun dan menghargai teman, baik di rumah, sekolah, maupun di masyarakat sekitar; 4.7 mencontohkan sikap rendah hati; 4.8 mencontohkan perilaku hemat; 4.9 mencontohkan perilaku jujur dalam kehidupan sehari-hari; 4.10 mencontohkan perilaku amanah dalam kehidupan sehari-hari; 4.11 mencontohkan perilaku hormat dan patuh kepada orangtua dan guru; 4.12 menunjukkan perilaku gemar membaca; 4.13 menunjukkan sikap pantang menyerah; 4.16 menceritakan kisah keteladan Nabi Ayyub a.s; 4.17 menceritakan kisah keteladan Nabi Zulkifli a.s; 4.18 menceritakan kisah keteladan Nabi Harun a.s; 4.19 menceritakan kisah keteladanan Nabi Musa a.s; 4.20 menceritakan kisah keteladanan Nabi Muhammad saw; dan 4.21 menceritakan kisah keteladanan Wali Songo; 4.5 menunjukkan perilaku jujur dalam kehidupan sehai-hari; 4.6 mencontohkan perilaku hormat dan patuh kepada orangtua dan guru; 4.7 mencontohka sikap saling menghargai sesama manusia; 4.8 mencontohkan sikap sederhana dalam kehidupan sehari-hari; 4.9 mencontohkan sikap ikhlas beramal dalam kehidupan sehari- hari; 4.12 menceritakan kisah keteladanan Nabi Dawud a.s; 4.13 menceritakan kisah keteladanan Nabi Sulaiman a.s; 4.14 menceritakan kisah keteladanan Nabi Ilyas a.s; 4.15 menceritakan kisah keteladanan Nabi Ilyasa' a.s; 4.16 menceritakan kisah keteladanan Nabi Muhammad saw; dan 4.17 menceritakan kisah keteladanan Luqman sebagaimana terdapat dalam Al Qur'an; 4.5 mencontohkan perilaku hormat dan patuh kepada orangtua, guru, dan sesama anggota keluarga; 4.6 menunjukkan sikap toleran dan simpatik terhadap sesama sebagai wujud dari pemahaman QS. Al-Kafirun; 4.8 menceritakan kisah keteladanan Nabi Yunus a.s; 4.9 menceritakan kisah keteladanan Nabi Zakariya a.s; 4.10 menceritakan kisah keteladanan Nabi Yahya a.s; 4.11 menceritakan kisah keteladanan Nabi Isa a.s; 4.12 menceritakan kisah keteladanan Nabi Muhammad saw; 4.13 menceritakan kisah 
keteladanan sahabat-sahabat Nabi Muhammad saw; dan 4.14 menceritakan kisah keteladanan Ashabul Kahfi sebagaima-na terdapat dalam Al-Qur'an.

Dari kurikulum, guru PAI menjabarkan praktikum ke dalam program semester. Dalam program semester ganjl, jumlah praktikum kelas 2, 4, dan 6 sebanyak 23 praktikum. Bentuk-bentuk praktikum menurut program semester rata-rata berjumlah 7-8 praktikum selama satu semester, dengan begitu pelaksanaan praktikum dalam satu materi/bab bisa terjadi 1-2 praktikum. sama seperti dalam kurikulum, bentuk praktikum tersebut mencakup aqidah, syari'ah, dan akhlak. Sesuai pendapat (Widayanti, 2018) ruang lingkup pembelajaran PAI di Sekolah Dasar meliputi Al-Qur'an dan Al-Hadist, aqidah, fiqih, dan akhlak.

Program semester adalah uraian dari program tahunan. Berisikan rumusan kegiatan belajar mengajar untuk satu semester yang kegiatannya dibuat berdasarkan pertimbangan alokasi waktu yang tersedia, jumlah pokok bahasan yang ada dalam semester tersebut dan frekuensi ujian yang disesuaikan dengan kalender pendidikan (Nurainun, 2019). Menurutnya, dengan disusun program semester maka guru PAI akan lebih mudah dalam menentukan alokasi waktu. Seperti yang dikatakan bahwa program semester disusun untuk menjadi pedoman dan batasan guru untuk menyajikan materi terhadap alokasi waktu selama satu semester (Nursobah dan Aflahah, 2019).

Yang termasuk ke dalam aqidah antara lain memiliki sikap sebagai Implementasi Iman kepada Allah; mengetahui keberadaan Allah melalui pengamatan terhadap makhluk ciptaan-Nya; memiliki sikap yang dipengaruhi oleh keimanan kepada malaikat-malaikat Allah; nama-nama Rasul Allah; menunjukkan sikap beriman kepada Qadha dan Qadar dalam kehidupan sehari-hari. Lingkup syari'ah meliputi menunjukkan hikmah mengeluarkan zakat, infaq, dan shadaqah, dan lingkup akhlak antara lain memiliki sikap berani bertanya sebagai praktik dari pemahaman QS. An-Nahl ayat 43; mencontohkan perilaku hidup bersih dan sehat; menunjukkan contoh perilaku kasih sayang kepada sesama; berperilaku kasih sayang sebagai praktik dari pemahaman QS. Al-Fatihah ayat 3; mencontohkan perilaku tolong-menolong dan kerja sama; menceritakan kisah keteladanan Nabi Muhammad SAW; santun dan menghargai teman; hormat dan patuh; rendah hati, hemat, jujur, dan amanah; memiliki sikap hormat dan patuh kepada orangtua; hormat dan patuh kepada guru; hormat dan patuh kepada sesama anggota keluarga; menunjukkan sikap toleransi dalam kehidupan sehari-hari; memiliki sikap simpati dalam kehidupan sehari-hari. Lingkup syari'ah lebih sedikit daripada aqidah dan akhlak.

Setelah dijabarkan ke dalam program semester, selanjutnya guru PAI menjabarkan praktikum ke dalam rencana pelaksanaan pembelajaran (RPP). RPP tertuang dalam Peraturan Pemerintah Republik Indonesia Nomor 19 Tahun 2005 tentang Standar Nasional Pendidikan Pasal 20. Dalam (Gora dan Sunarto, 2010) berpendapat bahwa RPP adalah rencana yang menggambarkan prosedur dan pengorganisasian pembelajaran untuk mencapai satu kompetensi dasar yang ditetapkan dalam standar isi dan dijabarkan dalam silabus. Maka, sebelum melaksanakan praktikum, guru PAI membuat rencana pelaksanaan pembelajaran (RPP). Bentuk praktikum di SD Negeri Cibabat Mandiri 5 dalam RPP kelas genap sebanyak 13 praktikum yang meliputi aqidah, syari'ah, dan akhlak.

Aqidah meliputi 4.5 (1) menggambar kaligrafi Al Khaliq; (2) menyalin dan mewarnai serta memberi keterangan gambar ciptaan Allah dan manusia; 4.3 menggambar salah satu kaligrafi Asmaul Husna (Al Adl, Al Adzhim, Al Basr); 4.2 menghapal 4 Asmaul Husna (As Shamad, Al Muqtadir, Al Muqaddim, Al Baaqi). Syari'ah meliputi 4.9 mempraktikkan wudu dan doanya dengan tertib dan benar; 4.14 mempraktikkan tata cara bersuci dari hadas kecil; 4.7 menghapal pengertian, macam, dan hukum zakat, dan akhlak meliputi 4.8 menggambar sikap tolong menolong dan kerjasama; 4.4 melakukan kegiatan yang menunjukkan hidup bersih dan sehat di rumah; 4.6, 4.9, 4.10, 4.11 menyebutkan contoh perilaku jujur, amanah, hormat dan patuh pada guru serta orangtua,santun serta menghargai teman; 4.16, 4.17, 4.18, 4.19 menceritakan dengan singkat salah satu dari kisah Nabi Ayyub, Nabi Zulkifli, Nabi Harun, atau Nabi Musa; 
DOI: 10.29313 / tjpi.v10i2.8580

4.13 menceritakan kisah salah satu sahabat Nabi (Abu Bakar, Utsman, Ali bin Abi Thalib). Pada masa pandemi seperti sekarang, RPP disusun dengan pertimbangan-pertimbangan tertentu. Pendapat lain mengatakan bahwa RPP merupakan suatu cara yang memuaskan disertai langkahlangkah antisipatif sebagai upaya penjabaran kurikulum yang dapat dijadikan acuan dan pedoman dalam melaksanakan pembelajaran (Prastowo, 2019). RPP hanya dijadikan landasan dan tidak selalu akurat.

Hal yang tidak jauh berbeda pada pelaksanaan praktikum pembelajaran PAI di SD Negeri Cibabat Mandiri 5 disesuaikan dengan arahan dan revisian dari pengawas. Karena pada masa pandemi seperti ini guru PAI dituntut untuk tidak membebani peserta didik, maka sebisa mungkin memodifikasi bentuk praktikum agar tetap terlaksana.

\section{Perencanaan Praktikum}

\section{Pembelajaran PAI pada Masa Pandemi Covid-19 di SD Negeri Cibabat Mandiri 5}

Sebelum pelaksanaan praktikum, guru PAI akan membuat perencanaan praktikum pembelajaran PAI agar praktikum yang dilaksanakan dapat berhasil dan maksimal. Sesuai pendapat (Majid dan Andayani, 2006) dikatakan bahwa perencanaan dapat diartikan sebagai proses penyusunan materi pelajaran, penggunaan media pengajaran, penggunaan pendekatan dan metode pengajaran, dan penilaian dalam suatu alokasi waktu yang akan dilaksanakan pada massa tertentu untuk mencapai tujuan yang telah ditentukan.

Berdasarkan temuan di lapangan, tujuan praktikum di SD Negeri Cibabat Mandiri 5 menjadikan peserta didik mampu dan terampil dalam aspek psikomoriknya. Selain aspek kognitif, guru pun tidak boleh mengesampingkan aspek psikomotorik dalam pembelajaran PAI, artinya apa yang dipelajari dapat diterapkan dalam kehidupan sehari-hari. Sesuai dengan pendapat (Burhanuddin, 2014) tujuan pembelajaran PAI yaitu agar siswa memahami, menghayati, meyakini, dan mengamalkan ajaran Islam sehingga menjadi manusia muslim yang beriman, bertakwa kepada Allah Swt dan berakhlak mulia. Sama dengan pendapat (Dudin, 2018) tujuan dari praktikum PAI ini diantaranya mendukung proses pembelajaran PAI dalam menumbuh kembangkan akidah melalui pemberian, pemupukan, dan pengembangan pengetahuan, penghayatan, pengamalan, pembiasaan, serta pengalaman peserta didik tentang agama Islam sehingga menjadi manusia muslim yang terus berkembang keimanan dan ketaqwaanya kepada Allah SWT, selanjutnya memperkuat aqidah, berkahlak mulia, memperluas pengetahuan agama dan rajin beribadah. Dalam jurnal (Yusuf, 2018) disebutkan bahwa bentuk perubahan dari hasil belajar mengenai aspek psikomotor meliputi perubahan-perubahan dalam segi bentuk-bentuk tindakan motorik.

Materi praktikum pembelajaran PAI di SD Negeri Cibabat Mandiri 5 pada masa pandemi covid-19 sesuai dengan kurikulum. Sesuai dengan pendapat (Tafsir, 1992) dalam penyampaian materi, hal yang tidak kalah pentingnya adalah kurikulum.

Kemudian, metode praktikum pembelajaran PAI di SD Negeri Cibabat Mandiri 5 pada masa pandemi covid-19 menggunakan beberapa metode yaitu metode daring, metode drill, metode demonstrasi, dan metode resitasi. Sesuai dengan pendapat (Falah, 2015) aspek metode, fungsinya untuk mencapai keberhasilan pendidikan dalam mencapai tujuan adalah ketepatan menentukan metode, sebab tidak mungkin materi pendidikan dapat diterima dengan baik kecuali disampaikan dengan metode yang tepat.

Adapun evaluasi praktikum pembelajaran PAI di SD Negeri Cibabat Mandiri 5 pada masa pandemi covid-19 disana menggunakan teknik penilaian produk, teknik unjuk kerja dan teknik project work. Seperti pendapat (Sudijono, 2016) proses/kegiatan untuk menentukan kemajuan pendidikan dibandingkan dengan tujuan yang telah ditentukan, dan merupakan usaha untuk memperoleh informasi berupa umpan balik (feed back) bagi penyempurnaan pendidikan. Evaluasi ini ditujukan kepada peserta didik yang melaksanakan praktikum pembelajaran PAI. Evaluasi yang dilakukan yaitu lebih kepada evaluasi proses dan evaluasi hasil. Seperti yang dikatakan (Wulan dan 
Rusdiana, 2014) evaluasi proses, yaitu evaluasi yang dilakukan terhadap proses atau kegiatan pendidikan atau pembelajaran yang sedang berlansung.

\section{Fasilitas yang Digunakan Sebagai Penunjang Praktikum}

Pembelajaran PAI pada Masa Pandemi Covid-19 di SD Negeri Cibabat Mandiri 5

Pelaksanaan praktikum pembelajaran PAI di SD Negeri Cibabat Mandiri 5 pada masa pandemi covid-19 tentunya membutuhkan fasilitas sebagai penunjang praktikum. Fasilitas ini termasuk ke dalam aspek pembelajaran atau bisa disamakan dengan sarana dan prasarana. Seperti yang dijelaskan (Falah, 2015) bahwa aspek sarana dan prasarana adalah untuk sebuah keberhasilan pendidikan, karena tanpa sarana-prasarana yang memadai pendidikan kurang maksimal dan tidak efektif. Sama dengan pendapat sebelumnya, (Bafadal, 2004) mengungkapkan bahwa sarana atau fasilitas belajar adalah semua perangkat peralatan, bahan, dan perabot yang secara langsung digunakan dalam proses belajar.

Berdasarkan temuan di lapangan, fasilitas yang digunakan praktikum masa pandemi covid19 di SD Negeri Cibabat Mandiri 5 itu beragam, namun yang paling penting yaitu HP/laptop dan kuota/wifi. Fasilitas-fasilitas yang lain yaitu buku agama, Al-Qur'an, juz amma, pensil/pulpen, buku tulis, HVS/buku gambar, penghapus/type-x, penggaris, spidol, pensil warna, crayon, tripod, sapu, lap pel, kemoceng, ember, materi-materi yang ibu share di grup, kran, air, gayung, kamar mandi, buku kisah-kisah Nabi, buku Asmaul Husna, dan buku kisah-kisah sahabat Rasulullah SAW. Sesuai pendapat (Arikunto dan Yuliana, 2008) fasilitas dibedakan menjadi 2 jenis, yaitu fasilitas fisik dan fasilitas uang. Sedangkan menurut (Hamalik, 2003) fasilitas ada 3 jenis antara lain media atau alat bantu belajar, peralatan dan perlengkapan belajar, serta ruangan belajar.

Tersedianya fasilitas tentu ada sumber yang menyediakan, saat masa pandemi covid-19 seperti ini, siswa melaksanakan pembelajaran di rumah (daring), maka fasilitas yang digunakan bersumber dari masing-masing/pribadi, dengan dibantu oleh orangtua. Sesuai dengan pendapat (Syah, 1999) orang tua juga ikut berperan penting dalam menyumbang tersedianya fasilitas belajar.

\section{Proses Praktikum Pembelajaran PAI pada Masa Pandemi Covid-19 di SD Negeri Cibabat Mandiri 5}

Dalam melakukan praktikum di SD Negeri Cibabat Mandiri 5 tentunya ada proses-proses yang dilaksanakan, mulai dari persiapan, pelaksanaan dan tindak lanjut praktikum. Sesuai dengan pendapat (Hamidah dkk, 2014) tahapan praktikum PAI dibagi menjadi tiga tahapan. Pertama, tahap pendahuluan, kedua tahap pelaksanaan, dan ketiga tahap pasca praktikum. Berdasarkan temuan di lapangan, langkah- langkah praktikum pembelajaran PAI di SD Negeri Cibabat Mandiri 5 dinilai terbatas karena secara daring.

Selama proses praktikum, ada pihak yang terlibat dalam pelaksanaan praktikum pembelajaran PAI, disamping peserta didik dan guru PAI, ada juga orangtua dan keluarga lainnya yang turut serta membantu mensukseskan proses praktikum. Sebagaimana pendapat (Hamalik, 2009) faktor yang mendukung hasil belajar pada diri peserta didik, seperti faktor keluarga yang meliputi cara orang tua mendidik, pengertian orang tua ataupun relasi antar anggota keluarga.

Selama proses pelaksanaan praktikum pembelajaran PAI tidaklah selalu mulus dan lancar, ada beberapa hambatan yang terjadi. Seperti yang dikatakan (Romlah, 2010) tentang kesanggupan seseorang untuk beradaptasi dalam berbagai situasi, hal ini terlihat bahwa peserta didik masih beradaptasi dalam pelaskanaan praktikum secara daring. Kemudian, siswa yang kurang berbakat dalam menulis arab, menggambar, mewarnai, sehingga melakukannya membutuhkan waktu yang lama.

Ketika ada hambatan tentunya akan ada solusinya, solusi tersebut diantaranya dengan terus dibimbing oleh orangtua. Seperti yang dikatakan cara orang tua mendidik, pengertian orang tua ataupun relasi antar anggota keluarga akan mempengaruhi hasil belajar siswa. Kemudian motivasi belajar dari orangtua, seperti yang dikatakan (Hamalik, 2009) diartikan sebagai suatu perubahan 
DOI: $10.29313 /$ tjpi.v10i2.8580

tenaga di dalam diri manusia yang di tandai oleh dorongan efektif dan reaksi-reaksi dalam usaha mencapai tujuan.

\section{Penilaian Praktikum Pembelajaran PAI pada Masa Pandemi Covid-19 di SD Negeri Cibabat Mandiri}

5

Setelah terlaksana praktikum pembelajaran PAI, maka akan ada penilaian. Sesuai pendapat (Sudijono, 2016) disebutkan bahwa penilaian berarti menilai sesuatu, sedangkan menilai yaitu mengambil keputusan terhadap sesuatu dengan mendasarkan diri atau berpegang pada ukuran baik atau buruk, sehat atau sakit, pandai atau bodoh dan sebagainya. Adapun menurut (Arikunto dan Yuliana, 2008) menilai berarti mengambil suatu keputusan terhadap sesuatu dengan ukuran baik buruk. Dalam penilaian adapun metode yang digunakannya.

Menurut Sudijono dalam (Anwar dan Fakhruddin, 2016) secara garis besar, teknik penilaian yang digunakan dalam pembelajaran dibagi menjadi 2, yaitu teknik tes dan teknik non tes. Adapun menurut (Majid, 2017) terdapat beberapa metode penilaian, antara lain penilaian tes, penilaian dengan observasi, penilaian dengan penugasan, penilaian dengan portofolio, penilaian dengan projek/tugas, penilaian produk, penialain inventori, penilaian dengan jurnal, penialaian teman sejawat dan penialaian diri sendiri. Temuan di lapangan menyatakan bahwa praktikum pembelajaran PAI pada masa pandemi covid-19 di SD Negeri Cibabat Mandiri 5 menggunakan tiga metode penilaian, diantaranya tes praktik, metode penilaian observasi dan metode penilaian penugasan.

Menurut KBBI alat merupakan benda yang dipakai untuk mengerjakan sesuatu atau untuk mencapai tujuan. Maka, alat penilaian merupakan benda yang digunakan dalam penilaian. Adapun alat penilaian praktikum pembelajaran PAI ini sangat sederhana, antara lain Al-Qur'an, buku Asmaul Husna, buku paket PAI, buku panduan shalat, video tentang kisah keteladanan Nabi, dan buku sejarah kebudayaan islam. Berdasarkan alat penilaian yang telah disusun, guru-guru dibimbing untuk menerapkan alat penilaian tersebut dalam proses pembelajaran dan juga di akhir pembelajaran (W.E dan B.W, 2027).

Adapun terkait proses penilaian sesuai pendapat (Arifin, 2014) proses penilaian merupakan bagian integral dari kegiatan pembelajaran yang dilakukan oleh pendidik untuk mengetahui tingkat pencapaian standar kompetensi lulusan, menggunakan acuan kriteria, dilakukan secara keseluruhan dan berkelanjutan, dan harus sesuai dengan pengalaman belajar yang ditempuh dengan proses pembelajaran. Adapun proses penilaiannya disesuaikan dengan indikator-indikator yang telah ditetapkan sebelumnya, serta ketepatan waktu dalam mengumpulkan hasil praktikum.

Dengan adanya hasil penilaian, maka guru akan mengetahui keberhasilan siswa dalam melaksanakan praktikum. Sesuai dengan penelitian yang dilakukan Wulan \& Rusdiana (2014) yang menyatakan dalam penelitiannya praktikum menjadi hasil nyata dari proses transformasi (Wulan dan Rusdiana, 2014). Seberapa jauh tingkat pencapaian/prestasi selama mengikuti program. Alat ukur: test pencapaian atau achievement test. Hasil penilaian praktikum pembelajaran PAI di SD Negeri Cibabat Mandiri 5 ini semua siswa memiliki nilai diatas 75 (KKM), sehingga tidak ada pengulangan praktikum.

Setelah dilakukan penilaian tentunya akan ada tindak lanjut dari hasil praktikum pembelajaran PAI ini, seperti yang dilakukan SD Negeri Cibabat Mandiri 5 yaitu bekerja sama dengan orangtua untuk mendorong putra/putrinya dalam memperbaiki praktikumnya. Sesuai pendapat (Arifin, 2014) kontinuitas, yang berarti hasil evaluasi yang diperoleh pada suatu waktu harus senantiasa dihubungkan dengan hasil-hasil pada waktu sebelumnya, sehingga dapat diperoleh gambaran yang jelas dan berarti. Dan menurut (Arifin, 2014) berkesinambungan, dilakukan secara teratur dan sambung-menyambung dari waktu ke waktu. 


\section{SIMPULAN}

Bentuk praktikum pembelajaran PAI pada masa pandemi covid-19 meliputi aqidah, syari'ah, dan akhlak, diantaranya melafalkan, menunjukkan hafalan, mengamati, mencontohkan, mempraktikkan, dan menceritakan kisah. Perencanaan praktikum dibuktikan dengan adanya penyusunan tujuan praktikum, materi praktikum, metode praktikum, serta evaluasi praktikum. Fasilitas utama yaitu HP/laptop, dan internet. Adapun fasilitas pendukung seperti buku paket, penghapus/type-x, penggaris, spidol, pensil warna, crayon, tripod, sapu, lap pel, kemoceng, ember, kran, air, dan buku referensi lain. Proses praktikum dimulai dari guru memberikan tugas prakikum lalu dilaksanakan oleh peserta didik dengan bimbingan orangtua atau keluarga. Penilaian praktikum dilihat dari hasil praktikum lalu dikomunikasikan dengan orangtua agar diimplementasikan dalam kehidupan.

\section{UCAPAN TERIMA KASIH}

Saya mengucapkan terima kasih kepada Tuhan yang maha Esa yang telah melancarkan penulisan jurnal penelitian ini. 
DOI: 10.29313 / tjpi.v10i2.8580

\section{DAFTAR PUSTAKA}

Anggito, A., \& Setiawan, J. (2018). Metodologi Penelitian Kualitatif. CV Jejak.

Anwar, S., \& Fakhruddin, A. (2016). Pelaksanaan Standar Penilaian Oleh Guru Pendidikan Agama Islam di Sekolah (Studi Evaluatif terhadap Guru PAI SMP dan SMA di Bandung). Jurnal Pendidikan Agama Islam-Ta'lim, 139-155.

Arifin, Z. (2014). Model Penelitian Kualitatif. PT Remaja Rosdakarya.

Arikunto;, S., \& Yuliana, L. (2008). Manajemen Pendidikan. Aditya Media.

Asyhar, R. (2012). Kreatif Mengembangkan Media Pembelajaran. Referensi.

Bafadal, I. (2004). Manajemen Perlengkapan Sekolah dan Aplikasinya. Bumi Aksara.

Burhanuddin, H. (2014). Rekonstruksi Sistem Pembelajaran Pendidikan Agama Islam di

Sekolah. Muaddib, 71-92.

Chamisijatin, L., \& Permana, F. H. (2019). No Title. UMMPress.

Darwin. (2018). Pengaruh Penguasaan Ilmu Tajwid dan Tahsin Terhadap Hasil Belajar Al-Quran (Studi kasus pada Siswa Madrasah Aliyah Negeri I Kendari Sulawesi Tenggara). Jurnal Fikratuna, 82-91.

Departemen Pendidikan Nasional. (2002). Kamus Besar Bahasa Indonesia Edisi Kedua. Balai Pustaka.

Dudin, A. (2018). Studi Kasus Laboratorium Pendidikan Agama Islam di SMAN 3

Bandung. EDUKASI: Jurnal Penelitian Pendidikan Agama Dan Keagamaan, 63-79.

Falah, A. (2015). Studi Analisis Aspek-Aspek Keberhasilan Pembelajaran PAI Di SDN 01 KarangMalang Gebog Kudus. Elemantary, 171-195.

Gora, W., \& Sunarto. (2010). Strategi Pembelajaran Inovatif berbasis TIK. PT Elex Media Komputindo.

Hadi, A. (2019). Kompetensi Guru PAI dalam Praktikum Materi Ibadah Praktis Di SMAN 2 Aceh Barat Daya.

Hamalik, O. (2003). Proses Belajar Mengajar. Bumi Aksara.

Hamalik, O. (2009). Psikologi Belajar dan Mengajar. Sinar Baru Algensindo.

Hamidah, A., Sari, E. N., \& Budianingsih, R. S. (2014). Persepsi Siswa Tentang Kegiatan

Praktikum di SMA Negeri 1 Kota Jambi. Jurnal Sainmatika, 49-59.

Huda, M. (2014). Model-model Pengajaran Dan Pembelajaran: Isu-isu Metodis dan Pragmatis.

Pustaka Pelajar.

Kisbiyanto. (2013). Studi Analisis Pengelolaan Praktikum Keagamaan Islam Perspektif

Kurikulum. ThufulA, 23-37.

Majid, A. (2017). Perencanaan Pembelajaran Mengembangkan Standar Kompetensi Guru. PT Remaja Rosdakarya.

Majid, A., \& Andayani, D. (2006). Pendidikan Agama Islam Berbasis Kompetensi. Remaja

Rosdakarya.

Nurainun. (2019). Analisis Perangkat Pembelajaran Guru Pendidikan Agama Islam Berdasarkan Kurikulum 2013 Di SMP Negeri 1 Percut Sei Tuan Deli Serdang.

Nursobah, A., \& Aflahah. (2019). Perencanaan Pembelajaran MI/SD. Duta Media Publishing. Prastowo, A. (2019). Analisis Pembelajara Tematik Terpadu. Prenada Media.

Pratiwi, D. K. N. (2017). Analisis Kesulitan Belajar Membaca Al-Qur'an Pada Siswa kelas VIII SMP Mubammadiyah 1 Surakarta Tahun Pelajaran 2016/2017.

Romlah. (2010). Psikologi Pendidikan. Universitas Muhammadiyah Malang.

Sudijono, A. (2016). Pengantar Evaluasi Pendidikan.

Sujono, B. I. (2010). Upaya Meningkatkan Kemampuan Shalat Siswa Kelas IV Melalui Metode

Demonstrasi di SD Negeri Kalimanggis Kaloran Temanggung Tahun Pelajaran 2009/2010.

Susi. (2020). Kejuaraan bidang PAI.

Syah, M. (1999). Psikologi Belajar. Logos.

Syamsinar. (2012). Peningkatan Keterampilan Berwudhu Murid Kelas II Melalui Metode Demonstrasi di Sekolah Dasar Negeri 003 Sialang Palas Kecamatan Lubuk. Dalam Kabupaten Siak. 
Tafsir, A. (1992). Ilmu Pendidikan dalam Perspektif Islam. Remaja Rosdakarya.

Tarjo. (2019). Metode Penelitian Sistem 3x Baca. Deepublish.

Ulan. (2020). Prestasi SD Negeri Cibabat Mandiri 5.

W.E, R., \& B.W, A. (2017). Penerapan Alat Penilaian Berbasis Kompetensi Pembelajaran Bahasa Indonesia Bagi Siswa SD Muhammadiyah 1 Malang. Jurnal Dedikasi, 83-94.

Widayanti, D. (2018). Penggunaan Model Pembelajaran Make a Match Dapat Meningkatkan Motivasi dan Hasil Belajar Materi Mengenal Malaikat dan Tugasnya pada Siswa Kelas IV SD Negeri III Jaten Tahun 2015/2016. Jurnal Pendidikan Dwija Utama, 13-21.

Wulan, E. R., \& Rusdiana, H. A. (2014). Evaluasi Pembelajaran Dengan Pendekatan 2013.

Pustaka Setia Bandung.

Yusuf, B. B. (2018). Konsep dan Indikator Pembelajaran Efektif. Jurnal Kajian Pembelajaran Dan Keilmuan, 13-20. 